\title{
Trade Dispute Settlement in the Tripartite Free Trade Area
}

\author{
Clarence Siziba \\ University of Bern, World Trade Institute \\ clarence.siziba@wti.org
}

Abstract

In 2015, the Heads of State and Government of COMESA, the EAC and SADC agreed to establish the Tripartite Free Trade Area (TFTA) extending from Cape to Cairo, encompassing all twenty-six members of the three groupings. While the TFTA negotiations are ongoing, it is necessary that member states are aware of their rights and obligations as well as the nature and power of the organs of the TFTA. This paper analyses dispute resolution bodies of the three regional economic communities making up the large trade bloc, in order to distil the most salient features which allow for effective dispute resolution. The study shows that it is necessary that regional judiciaries be allowed to operate independently and efficiently without undue interference from political elites, otherwise they stand to fail in executing their mandate.

Research for this paper was funded by the Swiss State Secretariat for Economic Affairs under the SECO / WTI Academic Cooperation Project, based at the World Trade Institute of the University of Bern, Switzerland.

SECO working papers are preliminary documents posted on the WTI website (www.wti.org) and widely circulated to stimulate discussion and critical comment. These papers have not been formally edited. Citations should refer to a "SECO / WTI Academic Cooperation Project" paper with appropriate reference made to the author(s).

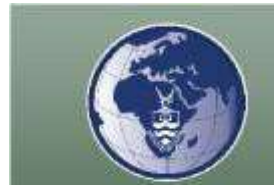




\section{INTRODUCTION}

Regional integration refers to the outcome of processes, including cooperative arrangements, the implementation of intergovernmental treaties and market-led processes, through which economies of countries in a region become more closely interconnected. ${ }^{1}$ These outcomes are essential to building markets, creating robust and diverse economies, increasing opportunities for growth, and attracting new sources of investment finance. Regional integration allows for economies of scale, promotes intra-regional trade and ensures that regional bodies have a greater role in global economic governance. If well and truly grounded in the socio-economic realities in which member states operate, regional integration is more likely to succeed and enhance the trade liberalisation agenda. ${ }^{2}$ However, it can pose serious dangers, especially given the multiple membership regional integration models prevailing at present. These multiple commitments can also lead to jurisdictional conflict and non-compliance.

'The presence of multiple regional courts with overlapping functions and jurisdiction may by itself defeat the whole purpose of establishing the respective regional organisations as economic zones to spearhead and accelerate the growth and economy of the people. It is not an incentive to foreign investors, who prefer certainty and predictability of decisions in the event a dispute emerges calling for judicial intervention. In this kind of situation there is no certainty or predictability, especially given

\footnotetext{
1 African Development Bank Group (ADB Group), "Regional Integration", http://www.afdb.org/en/topics-and-sectors/topics/regional-integration/ (Accessed 26.02.2015).

2 Donald A Calvert 'How the Multilateral Trade System Under the World Trade Organisation is Attempting to Reconcile the Contradictions \& Hurdles Posed by Regional Trade Agreements: An Analysis of Article XXIV of the General Agreement on Tariffs \& Trade' (Unpublished Masters Thesis, George Mason University, 2002).
} 
that one is not even sure of which court one should go to if a dispute arises. $^{3}$

The overriding role of dispute settlement bodies in regional integration initiatives is to foster predictability, transparency, accountability and participation of all member states as well as individuals conducting business in them. Sound governance and remedial measures are necessary for regional integration and development. Clarity around trade rules breeds a culture of trust which in turn facilitates greater trade; while the availability of a platform to protect the rights of investors creates opportunities for further investment.

This paper consists of five parts. The first section introduces the subject of regional integration at the multilateral and examines why countries establish regional economic communities. In essence, it details the arrangements that lead to the formation of these agreements and how this impacts on global trade relations. Part two continues in the vein of background material through a discussion of the African Economic Community (AEC) and how it is to be achieved before zooming in on the formation of the Tripartite Free Trade Area (TFTA). It principally lays the contextual basis for the establishment of the TFTA within the broader debate of the establishment of the AEC. The third unit provides an assessment of the problems and prospects faced by regional economic communities in their attempts to address disputes at the regional level. It raises pertinent issues affecting the manner in which disputes can be resolved. Part four draws attention to the dispute resolution mechanisms of COMESA, SADC and the EAC, as well as that of the soon to be established Tripartite Dispute Settlement Body. The aim is to draw out the salient

\footnotetext{
${ }^{3}$ John Eudes Ruhangisa 'The East African Court of Justice" in Rok Ajulu The Making of a Region: The Revival of the East African Community (2005) 107.
} 
features of dispute settlement in these communities to inform future trade dispute settlement measures. Finally, the fifth section consolidates the points raised and uses them as a basis for providing concrete recommendations for the TFTA dispute settlement mechanism.

\section{THE MULTILATERAL TRADING SYSTEM AND REGIONALISM}

(a) WTO Rules on Regional Integration

The legal provisions which regulate the formation and subsistence of regional trade agreements lie in a number of WTO Agreements: the General Agreement on Tariffs and Trade (GATT); the General Agreement on Trade in Services (GATS); and the Agreement on Differential and More Favourable Treatment, Reciprocity, and the Fuller Participation of Developing Countries (the Enabling Clause). Article XXIV of the GATT sets out how RTAs should operate. There are three major obligations in this regard: both internal and external trade requirements as well as a notification responsibility. In order for an RTA to pass WTO muster, it should seek to reduce substantially all barriers to trade amongst its members. ${ }^{4}$ Barriers to trade in respect of non-RTA members who are also WTO members must not be more restrictive than those obtaining prior to the conclusion of the RTA. ${ }^{5}$ The WTO has to be notified of the intention to create an RTA, subject to review by the Committee on Regional Trade Agreements (CRTA). ${ }^{6}$

The Enabling Clause provides for special and differential treatment for developing countries as long as the notification procedure is followed. In addition, no added

\footnotetext{
${ }^{4}$ Article XXIV:8 of the GATT 1994.

${ }^{5}$ Article XXIV:5 of the GATT 1994.

${ }^{6}$ Article XXIV:7 of the GATT 1994.
} 
barriers to trade should be created following such treatment. With respect to trade in services, Article V of the GATS provides for essentially the same requirements as obtain under GATT Article XXIV. However, arguments have been raised to the effect that the GATS is more lenient in its regional integration requirements than the GATT. ${ }^{7}$ While it is useful to have these arrangements in place, they are not without their faults. The CRTA has never come to a consensus regarding the compliance of any RTA which it has been asked to take notice of. ${ }^{8}$ In addition, the notification procedure does not seem to be working well. For instance, the Tripartite Free Trade Area is under negotiation in Africa, yet no notification procedures have as yet been implemented. Members often notify the CRTA after the formation of the RTA or choose not to make a notification at all. ${ }^{9}$ This limits the formation of RTAs in that the procedure is only effective insofar as states choose to comply. However, attempts have been made to improve the rules pertaining to regional trade agreements. ${ }^{10}$ Nevertheless, the prescriptions described above are useful in delineating the limits within which an RTA will be recognised. Despite its shortcomings, the monitoring and compliance mechanism offered by the CRTA is necessary in reigning in rogue elements in the multilateral trading system.

\footnotetext{
7 See Petros Constantinos Mavroidis 'Do Not Ask Too Many Questions: The Institutional Arrangements for Accommodating Regional Integration Within the WTO' in E Kwan Choi and James C Hartigan (eds.) Handbook of International Trade (2004) for a more detailed discussion.

${ }^{8}$ Joanna Langille 'Neither Constitution Nor Contract: Understanding the WTO by Examining the Legal Limits on Contracting Out Through Regional Trade Agreements' (2011) 86 NYU Law Review 1482 at 1506.

9 lbid.

${ }^{10}$ William J Davey and Andre Sapir 'The Soft Drinks Case: The WTO and Regional Agreements' (2009) 8 World Trade Review 5-23 at 20. The 1994 Understanding on the Interpretation of GATT Article XXIV gave power to the Dispute Settlement Body to review the consistency of preferential agreements with the WTO. In addition, the General Council Decision on the Transparency Mechanism for Regional Trade Agreements prescribed that RTA parties furnish the CRTA with detailed information to allow for greater transparency.
} 
According to the WTO, 349 RTAs have been notified to the Committee on Regional Trade Agreements. ${ }^{11}$ Of these, 206 were notified in terms of Article XXIV of the GATT 1994, 107 under GATS Article V and the remainder - 36 - under the Enabling Clause. However, there are many more RTAs that are in existence at present than those which have been notified to the WTO. The WTO itself admits that there are almost 500 RTAs in existence worldwide. ${ }^{12}$ Each WTO member is a party to at least one RTA. ${ }^{13}$ Both developed and developing country members of the WTO are party to RTAs, signifying that the motivation for entering into these agreements is rather complex.

(b) Why Regional Integration?

Countries choose to engage in regional trade forums because it is easier to reach agreement on concessions at a micro rather than a macro level. There are less chances of reaching deadlock in a smaller grouping than in a larger one where divergent interests compete for airplay in a small space. ${ }^{14}$ In addition, many developing countries are unhappy with the progress of trade negotiations in the WTO, especially in light of the deadlock reached in the Doha Round. Ismail notes that the GATT failed developing countries through the defensive role of developed countries. ${ }^{15}$ Developed countries are pushing for deeper trade and investment commitments from developing countries than is now possible given the divisions in the WTO. Thus by engaging in RTA negotiation and formation, developing countries are better empowered to tap into developed country markets. However, a secondary

\footnotetext{
${ }^{11}$ WTO Secretariat 'Regional Trade Agreements Information System' last accessed from http://rtais.wto.org/Ul/PublicAllRTAList.aspx on 16 August 2015.

${ }_{12}$ WTO 'Secretariat Facts and Figures' last accessed from http://www.wto.org/english/tratop e/region e/regfac e.htm on 16 August 2015.

${ }^{13}$ WTO 'Regional Trade Agreements' op cit.

${ }^{14}$ Ildiko Virag-Neumann 'Regional Trade Agreements and the WTO' $7^{\text {th }}$ International Conference on Management, Enterprise and Benchmarking, June 5-6 2009, Budapest, Hungary 385.

${ }^{15}$ Faizel Ismail Reforming the World Trade Organisation: Developing Countries in the Doha Round (2009) 12.
} 
reason for developing country participation in these arrangements may be the need to move away from a developed country dominated multilateral trading system to one in which they have a multi-polar trade regime.

Initially, the WTO encouraged the formation of RTAs because it was envisaged that they would be useful building blocks for the multilateral trading system. This is evident in the fact that free trade areas and customs unions were sanctioned since the formation of the GATT in 1947. The provisions of the GATT 1947 relating to RTAs were imported into the GATT 1994. Customs unions were deemed to be similar to single countries in trade negotiations as they maintained a common external tariff against non-members. ${ }^{16}$ However, questions began to arise relating to whether RTAs created or diverted trade.

Trade creation involves the generation of gains when consumers are able to purchase from the cheapest and most competitive source of supply. This occurs when RTA members switch from inefficient domestic producers and import from more efficient producers from other members of the RTA. ${ }^{17}$ Conversely, trade diversion occurs when members switch imports from low-cost production in the multilateral system and import more from higher-cost producers in the partner countries. ${ }^{18}$ This in turn means that there are fewer welfare gains from regional trade. Although trade diversion may occur after the formation of an RTA, the fact that states are continually signing these agreements is testimony to their commitment to liberalising trade, albeit at a smaller scale. Trade diversion and trade creation can operate within the same regional framework, however, the net effect when the two

\footnotetext{
${ }^{16}$ Michael J Trebilcock Understanding Trade Law (2011) 44.

${ }^{17}$ Pal, P 'Regional Trade Agreements in a Multilateral Trade Regime: An Overview' (2004) 2 last accessed from http://www.networkideas.org/feathm/may2004/survey paper RTA.pdf on 16 August 2015.

${ }^{18}$ Ibid.
} 
are balanced is what will signify whether the regional trade agreement is successful or not.

IV AFRICAN REGIONAL INTEGRATION

(a) The African Economic Community

The African regional economic integration debate stems from the formation of the Organisation of African Unity in $1963 .^{19}$ The Lagos Plan of Action concluded following a 1980 Summit visualised as a blueprint for the economic and political development of Africa. $^{20}$ African statesmen envisaged the formation an African Economic Community (AEC). A treaty for the establishment of the AEC was signed in $1991 .^{21}$ The Abuja Treaty was an improvement on the Lagos Plan of Action in that it was more specific regarding economic, social and cultural development in Africa. The treaty aimed at the linear progression of the AEC based on existing regional arrangements to an Africa-wide economic bloc. ${ }^{22}$ In 2002, the African Union (AU) replaced the OAU, with the commitment to regional integration being iterated in the new treaty. ${ }^{23}$ This led to the establishment of the New Partnership for Africa's Development (NEPAD), but it still hinged on development and economic integration at a sub-regional level.

\footnotetext{
${ }^{19}$ Formed following the independence of African states from their colonial rulers to spearhead development and the African Renaissance. See generally Henry Kyambalesa and Mathurin C Houngnikpo Economic Integration and Development in Africa (2006).

${ }^{20}$ Victor AO Adetula 'Regional integration in Africa: Prospect for Closer Cooperation Between West, East and Southern Africa' (2004) Paper presented at the meeting of IDASA/FREDSKORPSET Research Exchange Programme - Governance and Democracy, Johannesburg 11-12.

${ }_{21}$ Treaty Establishing the African Economic Community 1991, also known as the Abuja Treaty.

22 The treaty foresaw regional integration progressing in six stages: the strengthening of existing regional arrangements; tariff liberalisation and phasing out of non-tariff barriers regionally; the formation of free trade areas and customs unions; tariff liberalisation amongst the regional groupings; the formation of a monetary union; and eventually the formation of the African Economic Community.

${ }^{23}$ Constitutive Act of the African Union.
} 
Discussions on regional economic integration in Africa tend to focus more on issues around the value-add in combining economic might within the region, to the detriment of the legal issues ensuing there from. ${ }^{24}$ Even more glaring in the omissions is the "after thought" accorded to dispute settlement, both within the region itself, and at the level of the disjuncture between regional and national systems of law in relation to trade. Furthermore, while regional trade agreements are established in terms of the law of the World Trade Organisation (WTO), there is sometimes a gap between the two legal systems. It is important therefore that regional trade agreements adhere to the law of the WTO, which, while imperfect, provides a standard according to which decisions can be made and enforced.

While deliberations on the Tripartite Free Trade Area (TFTA) ${ }^{25}$ were preceded by the AEC Treaty and NEPAD, the TFTA will feed into the broader African regional integration agenda, since it is one of the blocks through which full African integration will be achieved. The idea is to use the TFTA coalition as a springboard from which full regional integration will ensue. It envisages a progression along the lines of that of the European Union from free trade area to customs union then common market and eventually monetary and political integration. Nevertheless, given the recent challenges experienced in the Eurozone as well as the slow progress in implementing existing integration initiatives on the continent, it is time to reassess the best way forward and define the "African way" of integration. ${ }^{26}$ African leaders need to move away from abstract and grandiose notions to more pragmatic solutions to the integration conundrum. We should not ignore the lessons learnt from the

\footnotetext{
${ }^{24}$ Richard F Oppong Legal Aspects of Economic Integration in Africa (2011) 12.

${ }^{25}$ Proposed amalgamation of the Common Market for Eastern and Southern Africa (COMESA), the East African Community (EAC) and the Southern African Development Community (SADC).

${ }^{26}$ The WTO has noted that African countries are lagging behind in terms of effective regional integration models - WTO The WTO and Preferential Trade Agreements: From Co-existence to Coherence (2011).
} 
"European" and "ASEAN" ways, for example, but it is critical that the approach of the continent reflects the realities of economic development and the global economy. ${ }^{27}$ This is why it then becomes necessary to also include the development of an appropriate trade dispute resolution mechanism based on what works for Africa.

(b) The Tripartite Free Trade Area

In 2008, Heads of State and Government of the Common Market for Eastern and Southern Africa (COMESA), the East African Community (EAC) and the Southern African Development Community (SADC) agreed to establish a free trade area extending from Cape to Cairo and encompassing all twenty six members of the three groupings. A Draft Tripartite Free Trade Area (TFTA) Agreement was finalised in December $2010 .^{28}$ TFTA negotiations commenced at a Summit held in South Africa in June 2011. The objectives of the TFTA as stated at the first COMESA-EAC-SADC Tripartite Summit in October 2008 are to: promote trade in the region through creation of a wider market; increase inter-REC and extra-REC investment flows; enhance competitiveness of the region in the globalised environment due to improved production improve efficiency and value addition; develop cross-regional infrastructure; develop inter-REC financial and capital systems which will deepen financial intermediation; and strengthen the region's negotiating positions in multilateral and bilateral trade arrangements. ${ }^{29}$

\footnotetext{
${ }^{27}$ Catherine Grant and Clarence Siziba 'African Leaders Commit to Better Trade Relations' (2012) last accessed from http://www.thetradebeat.com/authors/catherine-grant-makokera/item/36-africanleaders-commit-to-better-trade-relations on 16 August 2015.

${ }^{28}$ Draft Agreement Establishing the COMESA-EAC-SADC Free Trade Area (2010) last accessed from $\quad$ http://www.tralac.org/wpcontent/blogs.dir/12/files/2011/uploads/Draft Tripartite FTA Agreement Revised Dec 2010.pdf on 16 August 2015.

${ }^{29}$ Article 4 of the Draft TFTA Agreement.
} 
Essentially, this means that the proponents of the TFTA envision a development through trade outcome. This is not much different from the vision of African statesmen since the inception of the OAU, however, at present, the discussion had been enlarged to include greater competitiveness for the region as well as a better negotiating position. The overarching goal of the three regional organisations is to expand trade, alleviate poverty and improve the quality of life of the population of the Member States. The TFTA is also an effort to rationalise the problem of overlapping memberships of the RECs in the region. COMESA has 19 Member States of which eight are also members of SADC and four of the EAC; the EAC has five members, with four being members of COMESA and one a member of SADC; and lastly, SADC has 15 members, eight of which belong to COMESA as well and one to the EAC. $^{30}$

The TFTA negotiations were launched on 12 June 2011 at the Second Tripartite Summit. The Tripartite process will adopt a three-pronged approach based on market integration in the TFTA, infrastructure development and industrial development. ${ }^{31}$ The negotiations are to take place in two phases: (i) trade in goods and (ii) the free movement of business persons in two separate but parallel tracks; followed by (ii) services, intellectual property rights, competition policy and traderelated areas. ${ }^{32}$ Even as the negotiating agenda may be laudable, it is disheartening to note that the negotiating strategy is not being pushed at REC level, but rather at

30 COMESA Members: Burundi, Comoros, Djibouti, Egypt, Eritrea, Ethiopia, Kenya, Libya, Madagascar, Malawi, Mauritius, Rwanda, Seychelles, Sudan, Swaziland, Uganda, Zambia, Zimbabwe; EAC Members: Burundi, Kenya, Rwanda, Tanzania, Uganda; SADC Members: Angola, Botswana, Democratic Republic of Congo, Lesotho, Malawi, Mauritius, Mozambique, Namibia, Seychelles, South Africa, Swaziland, Tanzania, Zimbabwe (Madagascar currently suspended).

${ }^{31}$ COMESA, EAC and SADC Communiqué of the Second COMESA-EAC-SADC Tripartite Summit, 12 June 2011, Johannesburg, South Africa.

32 COMESA, EAC and SADC, Declaration Launching the Negotiations for the Establishment of the Tripartite Free Trade Area, 12 June 2011. 
the individual country plane. The TFTA Agreement was signed on June 102015. While negotiations as to the meat of the AGrement are ongoing, it is necessary to look at the implications that its establishment has on trade relations not only among member states, but also between the proposed block and external partners. Granted, the Draft Agreement is merely "a draft", however, negotiations are moving forward based on its contents and it is likely to form a huge bulk of the final agreement upon signature at a future date..$^{33}$

What states undertake to do in terms of the Agreement should be enforceable. 'A rules-based regime provides certainty, predictability and transparency for regional trade and investment. ${ }^{34}$ The TFTA is a rules-based initiative in that it is established in terms of GATT Article XXIV and the Enabling Clause. Twenty of the twenty-six states involved in the formulation of the TFTA are also members of the WTO, ${ }^{35}$ hence such compliance is required. States are better able to pursue their obligations where there is clarity in terms of rules of engagement. This is not to say that political will is not important in state relations, however, at the most basic level of state interaction, lucid regulations assist in state practice.

Effective dispute resolution and implementation of decisions will aid in this process. Indeed, former Director General of the WTO, Michael Moore, said that 'dispute settlement is the backbone of a multilateral trading system' ${ }^{36}$ With a dispute settlement mechanism, the commitments that states make in trade agreements are

\footnotetext{
${ }^{33}$ Article 50 of the Draft Tripartite Agreement provides that the Agreement shall come into effect upon ratification by two thirds of the members the trading bloc.

${ }^{34}$ T Hartzenberg 'Introduction' in Trudi Hartzenberg et al Cape to Cairo: Making the Tripartite Free Trade Area Work (2011) iii.

${ }^{35}$ Ethiopia, Comoros, Sudan, Libya, Seychelles and Eritrea are not members yet. Of the 6 nonmembers, 5 have Observer status at the WTO. The first three have already started accession negotiations.

${ }^{36}$ Quoted by Amos Saurombe 'Regional Integration Agenda for SADC "Caught in the Winds of Change": Problems and Prospects' (2009) 4 Journal of International Commercial Law and Technology 103.
} 
ascribed even more practical value. Trade dispute settlement in Africa has not received as much airplay as it should. In fact, in some jurisdictions, trade disputes have not been heard. This is in spite of the existence of trade dispute resolution mechanisms within the three regional economic communities (RECS). For a variety of reasons, member states in the three RECS clearly need to improve their commitment to a rules-based regional integration agenda. Integration not only relates to the benefits stemming from the alliance, but also the practical reality around issues of compliance and the enforcement of agreements.

\section{PROBLEMS AND PROSPECTS FOR EFFECTIVE DISPUTE RESOLUTION}

\section{(a) Requirements for Effective Dispute Resolution}

The fact that the TFTA is a rules-based agglomeration is advantageous in that it is clear what members ought to adhere to in terms of their rights and obligations. Just as the WTO system is plain in its trade liberalisation and non-discrimination ethos, clear rules will allow member states to conduct themselves according to the dictates of the TFTA Agreement. ${ }^{37}$ This is also useful given the fact that while states are in principle equal in international law, the reality is something different altogether. $\mathrm{A}$ rules-based approach allows even weaker states to experience somewhat the same equality and participation at the multilateral level. ${ }^{38}$

An institution designed for the resolution of disputes must subsist for there to be a practical dimension to the dispute settlement understanding. It is not enough to have rules without an adjudication process separate from the day to day operation of an

\footnotetext{
${ }^{37}$ The trade liberalisation agenda of the WTO rests on the standard of non-discrimination, which is amplified in two principles: most-favoured nation (MFN) and national treatment (NT) - Articles I and III of the GATT.

${ }^{38}$ Gerhard Erasmus 'The Tripartite FTA: Requirements for Effective Dispute Resolution' in Trudi Hartzenberg et al Cape to Cairo: Making the Tripartite Free Trade Area Work (2011) 86.
} 
organisation. An independent judicial arm will ensure that states comply with the mandate of the organisation. ${ }^{39}$ Rules of procedure are also very important as they will determine the adjudication of disputes and how decisions will be implemented.

The manner in which disputes are resolved is also instrumental in the determination of the effectiveness of a dispute resolution mechanism. Under the GATT, consultations and diplomatic efforts were used to resolve disputes. ${ }^{40}$ In the WTO, the dispute settlement mechanism outlines powers, procedures and outcomes in the realm of trade dispute resolution. ${ }^{41}$ There are 4 major steps in the WTO dispute settlement procedure : consultation, panel proceedings, appellate review and implementation and enforcement. ${ }^{42}$ This system envisages the settlement of disputes as between parties. Only at such point as they fail to do so will a Panel be established. Decisions under the GATT were reached via consensus; where there was no consensus, there could be no resolution. At the WTO, the Panel Report is adopted through the reverse consensus method; this means that the Report will be adopted should there be no consensus against its adoption. ${ }^{43}$ This method is useful in ensuring that decisions are reached expeditiously.

Finally, the enforcement of rulings is probably the most important element of the dispute settlement conundrum. Rules and legal action do not accomplish much without the implementation of decisions. Indeed, for the rules to be deemed to have

\footnotetext{
${ }^{39}$ FB William Kelly 'An Independent Judiciary: The Core of the Rule of Law' International Centre for Criminal Justice Reform and Criminal Justice Policy, Vancouver, Canada last accessed from http://www.icclr.law.ubc.ca/Publications/Reports/An Independant Judiciary.pdf on 16 August 2015.

${ }^{40}$ Erasmus 'The Tripartite FTA' at 88-89.

${ }^{41}$ Annex 2 - Understanding on Rules and Procedures Governing the Settlement of Disputes, also known as the Dispute Settlement Understanding (DSU).

${ }^{42}$ Jeanne J. Grimmett 'Dispute Settlement in the World Trade Organization: An Overview' CRS Report for Congress, September 142006 last accessed from http://fpc.state.gov/documents/organization/74910.pdf on 16 August 2015.

${ }^{43}$ Erasmus 'The Tripartite FTA' op cit. See also Bruce Wilson 'Compliance by WTO Members with Adverse WTO Dispute Settlement Rulings: The Record to Date' (2007) 10 Journal of International Economic Law 397-403.
} 
an effect and acquire the respect and recognition they deserve, enforcement should be seen to not only be possible, but also effective. ${ }^{44}$

The WTO dispute settlement system may not be the best, however, it is certainly the most instructive when it comes to the resolution of disputes in the area of international trade. ${ }^{45}$ It is not a standard according to which all other trade dispute settlement bodies should function, but rather a useful springboard from which the debate on trade dispute settlement at the regional level can be launched.

\section{(b) Challenges Faced by the RECs}

The question of increased markets through regional integration has always been high on the agenda of the three RECs. This is primarily because of the low levels of industrialisation that result in countries trading in primary or simple manufactured products, asymmetric product complementarities in the region, and the small populations in many countries. The question of expanded and new markets in the wake of the TFTA is also challenged by the low levels of intra-REC trade. There are reports of SADC and the EAC showing the highest levels of intra-REC trade in Africa $^{46}$ but the nature of that trade has to be taken into consideration. Economic polarisation is a real threat with South Africa, Kenya and Egypt in a likely position to reap most benefits from the TFTA as they currently have a high trade surplus with other countries in the region.

\footnotetext{
${ }^{44}$ Wilson 'Compliance by WTO Members' op cit.

${ }^{45}$ Surya P Subedi 'WTO Dispute Settlement Mechanism as a New Technique for Settling Disputes in International Law' in Duncan French, Matthew Saul, Nigel D. White (eds.) International Law and Dispute Settlement: New Problems and Techniques (2010). Subedi points out that critics argue that this system is ineffective insofar as monitoring compliance of great powers is concerned.

${ }^{46}$ African Union, "Trade Liberalisation, Investment and Economic Integration in African Regional Economic Communities Towards the African Common Market and Economic Community" AU Conference of Ministers of Trade, $6^{\text {th }}$ Ordinary Session, $29^{\text {th }}$ October - November 2010, Kigali, Rwanda.
} 
There is also the challenge of protectionist trade regimes in the region and the overdependence on customs revenue. Tariffs contribute $30 \%$ of the total central government recurrent revenue in Tanzania, Uganda and Zimbabwe and $40 \%$ in Comoros, Mauritius and Zambia. ${ }^{47}$ These countries may feel pressured to keep their import tariffs high in order to protect their revenue sources. The TFTA demands that countries either expand their effective tax bases or find alternative revenue sources, especially in circumstances where there might be a contraction of previously protected industries due to the TFTA ${ }^{48}$ However, this impact may be fairly limited given the low levels of intra-regional trade and the existing preferential tariff arrangements under bilateral agreements and REC FTAs.

The TFTA also seeks to eliminate the problem of overlapping membership of RECs and the multiplicity of trading arrangements. There will be difficulties due to the different levels of integration of COMESA's 19 members, 14 are trading at a FTA level while three are still trading under the Preferential Trading Area (PTA). Despite the launch of the COMESA Customs Union (CU) in 2010, it is yet to be implemented. SADC has 15 members (including Madagascar which is currently suspended), it launched its FTA in 2008, and 12 are implementing the FTA while three are not yet doing so. ${ }^{49}$

The biggest challenge comes from the countries that are not part of any trading arrangement in the region, ${ }^{50}$ but there is also the issue of CUs versus FTA arrangements. Where, for instance, the EAC might be charging high tariffs on

\footnotetext{
${ }^{47}$ Bohela Lunogelo \& AV Mbilinyi, 'Convergence of Comesa-SADC-EAC Regional Frameworks', The Economic and Social Research Foundation. Paper presented at the Annual Forum for Private, Public and Academia Partnership on Trade Policy and Negotiations organised by the Ministry of Industry, Trade and Marketing, Tanzania, on 26 October 2009.

${ }^{48}$ Tshidiso Disenyana, 'Towards an EAC, COMESA and SADC Free Trade Area: Issues and Challenges' SAllA Occasional Paper, October 2009.

${ }^{49}$ Angola, DRC and Malawi.

${ }^{50}$ Angola, DRC, Eritrea and Ethiopia.
} 
external imports, COMESA and SADC are apparently in support of free trade with countries outside their regions. ${ }^{51}$ Problems which may rise between states include access to markets through what Braude calls 'membership back doors. ${ }^{52}$ This can occur, for instance, through the dumping of Egyptian products in Uganda through Kenya. Similarly, problems could arise with products from South Africa entering the EAC through Tanzania. These are issues that would need to be addressed at the negotiating stage to ensure that these 'membership back doors' are not used to the detriment of other trade partners.

Moreover, the negotiation of trading arrangements with MERCOSUR and other external parties also poses a threat to the TFTA. ${ }^{53}$ This is particularly with regard to the Economic Partnership Agreement (EPA) negotiations with the EU. ${ }^{54}$ These have revealed massive holes in the unity of the RECs with countries failing to harmonise positions when dealing with the EU, hence resulting in a patchwork of potential EPA agreements.

Limited human and financial capacity still plagues the RECs as well as their members. The negotiating capacity of member states, in terms both of skills and manpower, is limited: there are thin staff complements at the REC Secretariats, and

\footnotetext{
51 United Nations Economic Commission for Africa (UNECA), "Final Report: Study on the Establishment of Inter-REC's Free Trade Areas in Africa Drawing on Lessons from the ComesaSADC-EAC FTA Experience" UNECA, Addis Ababa, Ethiopia. 2 May 2011.

${ }^{52}$ Wolfe Braude Regional Integration in Africa: Lessons from the East African Community (2008) 256.

53 Disenyana, op.cit.

${ }^{54}$ Scott McDonald \& Terrie Walmsley 'Bilateral Free Trade Agreements and Customs Unions: The Impact of the EU Republic of South Africa Free Trade Agreement on Botswana' GTAP Working $\begin{array}{lllll}\text { Papers } & \text { Paper } & 28 & \text { last } & \text { accessed }\end{array}$ http://docs.lib.purdue.edu/cgi/viewcontent.cgi?article=1028\&context=gtapwp\&seiredir=1\&referer=http\%3A\%2F\%2Fscholar.google.co.za\%2Fscholar\%3Fq\%3Dsouth\%2Bafrica\%2BEU \%2Btrade\%2Bagreement\%2BimpACT\%26hl\%3Den\%26as sdt\%3D0\%2C5\%26as vis\%3D1\#search =\%22south\%20africa\%20EU\%20trade\%20agreement\%20impACT\%22 on 16 August 2015.
} 
limited funds for research and analyses in preparation for the negotiations. ${ }^{55}$ There are also the financial demands associated with the creation of the TFTA, such the cost of providing the necessary infrastructure to facilitate trade and compensatory and adjustment costs for those Member States that will be adversely affected. ${ }^{56}$ These issues have not been canvassed by the RECs to date and may pose problems in the future if not properly addressed.

While there seems to be substantial support and enthusiasm for the TFTA across the wider region, political will and commitment to its implementation is a different issue. This problem has long manifested itself in the individual RECs, and is mostly attributed to the unwillingness by African states to cede any amount of sovereignty to a regional entity and to the prioritisation of domestic interests over regional ones. ${ }^{57}$ The rhetoric of political will in favour of integration has not been sufficiently met with the requisite action.

In the preparations for the TFTA, it has been reported that countries have been missing meetings and have also been late in submitting their responses to documents. ${ }^{58}$ It is likely that the issue of tariff liberalisation will also meet with some resistance from domestic constituencies, particularly in protected industries, and this will have significant impact on the commitment to liberalise. Coupled with the issue of political will and commitment in general is that of political instability in the region a factor which TFTA Member States will have to contend with as it affects trade.

\footnotetext{
${ }^{55}$ OECD and WTO, 'Aid for Trade Case Story: UK - Negotiating the COMESA-EAC-SADC Tripartite FTA' 31 January 2011 last accessed from http://www.oecd.org/aidfortrade/47407301.pdf on 23 August 2015.

${ }^{56}$ UNECA, op.cit.

${ }^{57}$ Mzukisi Qobo 'The Challenges of Regional Integration in Africa In the Context of Globalisation and the Prospects for a United States of Africa' ISS Paper 145, June 2007 last accessed from http://dspace.cigilibrary.org/ispui/bitstream/123456789/31112/1/PAPER145H.pdf?1 on 16 August 2015.

58 Ibid.
} 
Zimbabwe is a good example while Malawi is also going through some significant political upheavals. Both countries have sought derogations from their SADC FTA commitments. ${ }^{59}$

The EAC is part of the Great Lakes Region, which is prone to conflict. It is thus necessary to explore the nexus between trade and security to ensure that as markets open up with the TFTA initiative; trade benefits are not lost to criminal activities. $^{60}$ If criminal activities are not protected against, there could be serious repercussions for the viability of the T-FTA which could indeed result in regional instability and be detrimental to regional trade. Sea-borne trade is still very important to Africa, yet East Africa is battling with piracy (COST). Such disruptions to trade could lead to disputes arising between states regarding the movement of people (refugees and economic immigrants), border issues and greater trade facilitation costs in certain countries compared to others, to the detriment of the TFTA.

In the move towards merging the three RECs, institutional harmonisation will be a challenge, particularly as the current strategy on trade liberalisation leaves the RECs free to pursue their integration agendas undisturbed. A merger would entail dissolution (at least in part) of the three RECs in favour of a new expanded one. If this is still to happen, the approach has to be structured to make the process easier when it is time. ${ }^{61} \mathrm{~A}$ merger will entail a very extensive harmonisation programme, particularly given the different legal and institutional regimes subsisting in each REC.

\footnotetext{
${ }^{59}$ Staff Reporter 'Focus on the Tricks of Trade, Hears SADC' Mail \& Guardian 10 September 2011 last accessed from http://mg.co.za/article/2011-09-10-focus-on-the-tricks-of-trade-centre-tells-sadc on 16 August 2015.

${ }^{60}$ Ruhangisa op cit at 101.

${ }^{61}$ An instructive discussion on harmonisation of laws is detailed by Polina Dlagnekova 'The Need to Harmonise Trade-Related Laws Within Countries of the African Union: An Introduction to the Problems Posed by Legal Divergence' Paper prepared for the Southern African Society of Legal
} 


\section{DISPUTE RESOLUTION AT THE REGIONAL LEVEL}

\section{(a) The COMESA Court of Justice}

The Preferential Trade Area for Eastern and Southern Africa (PTA), established in 1981, became COMESA in 1993 in line with Article 29 of the PTA itself which called for the development of the PTA into a common market and eventually into an economic community. ${ }^{62}$ COMESA was established primarily as a vehicle for trade and economic development, and its objectives are economically orientated. ${ }^{63}$ It is interesting to note that one of the key objectives is to contribute towards the establishment, progress and the realisation of the objectives of the African Economic Community.$^{64}$ Evidently, the overall integration strategy of the AEC is important to COMESA members.

The COMESA Court of Justice (CoJ) which is composed of seven judges appointed by the Authority, and whose function is to ensure adherence to law in the interpretation and application of the COMESA Treaty as well as to adjudicate upon all matters referred to it pursuant to the COMESA Treaty. Article 19 tasks the CoJ with the interpretation and application of treaty law; exclusive jurisdiction over matters arising in and out of the COMESA Treaty is granted to the court. ${ }^{65} \mathrm{In}$ addition, the court has jurisdiction to give Advisory Opinions regarding questions of law relating to the Treaty. ${ }^{66}$ Disputes between COMESA employees and the

\footnotetext{
Historian's Session on "Harmonisation of Laws within the African Union", South African Law Teachers Conference held at the University of Pretoria, Jan 2008.

${ }^{62}$ Preamble to the COMESA Treaty.

${ }^{63}$ Article 3 of the COMESA Treaty.

${ }^{64}$ Article 3(f) of the COMESA Treaty. At its establishment, COMESA's main priority was the creation of a FTA by 2000, and this was achieved. In 2009, the COMESA Heads of State launched the COMESA Customs Union but this has yet to enter into force.

${ }^{65}$ Article 34(1).

${ }^{66}$ Article 32(1).
} 
Authority may also be heard by the court. ${ }^{67}$ All judgements of the CoJ are final and conclusive and not open to appeal. ${ }^{68}$ Decisions of the court have precedence over those of national courts of Member states. ${ }^{69}$ The seat of the CoJ is in Khartoum, Sudan. Seven judges appointed by the COMESA Authority based on their qualifications as distinguished judicial officers in their national courts comprise the court. $^{70}$ They are appointed for a period of 5 years, which period is renewable for a second term. ${ }^{71}$

Both the COMESA and EAC Courts provide for arbitration where commercial disputes have arisen. ${ }^{72}$ Arbitration allows disputes to be resolved without resorting to litigation, which is expensive and time-consuming. By contrast, SADC, and presently, the TFTA Agreement do not allow individuals to directly access the court for redress. $^{73}$ This could pose major problems for the application of treaty law between the RECS as they come together in the TFTA.

According to Article 23 of the DSU, the DSB has exclusive jurisdiction over any disputes arising from the WTO covered agreements. ${ }^{74}$ At the WTO, only states may bring disputes for adjudication by the DSB; individuals do not have the same privilege. However, at the regional level, individuals may approach international tribunals for redress. ${ }^{75}$ Individuals may not always be able to lobby their governments to institute proceedings against violating states, hence giving private

\footnotetext{
${ }^{67}$ Article 27.

${ }^{68}$ Article 31.

${ }^{69}$ Article Art 29(2).

70 Article 20.

${ }^{71}$ Article 21(1).

${ }^{72}$ Article 28 of the COMESA Treaty and Article 32 of the EAC Treatty; Ruhangisa 'The East African Court of Justice' 96.

${ }^{73}$ The SADC Tribunal was suspended in August 2012; Article 3 of the Tripartite Dispute Settlement ANNEX provides that it applies only to states.

${ }^{74}$ WTO Charter, GATT, GATS, and TRIPS.

75 See Article 30 of the Treaty for the Establishment of the EAC and Article 26 of the COMESA Treaty. Until recently, Artticle 18 of the SADC Protocol on Tribunal also applied.
} 
parties standing before regional courts allows for greater justice to be served. Given the fact that Africa has a large informal business sector, allowing individuals to approach the tribunals for the redress of international trade disputes would be a positive step. It would be ideal as well to incorporate the exhaustion of local remedies in the TFTA prior to instituting proceedings at the regional level.

In Eastern and Southern African Trade Bank $v$ Ogang ${ }^{76}$ an employee of the PTA Bank sought an order suspending a decision of the bank's board of directors. The bank claimed that the court had no jurisdiction over it on the basis that it was an independent institution, not an organ of COMESA. The court rejected this argument, citing the fact that the bank was created under the auspices of Article 174 of the COMESA Treaty, meaning that it was indeed an organ of COMESA. This case has two-fold significance: it affirmed the right of individuals to appear before the court and highlighted that the CoJ is also charged with oversight of relational issues relating to the structure and functions of all Treaty organs.

(b) The East African Court of Justice

Trade and economic integration in the EAC can be traced as far back as the colonial era. ${ }^{77}$ In 1917 Kenya and Uganda entered into a Customs Union which was joined by the then Tanganyika (now Tanzania) in 1927 and together they formed the East African Community in 1967. This EAC was dissolved in 1977 owing to trade polarisation effects arising from the economic dominance of Kenya and the 'political, ideological and personal differences between the respective leaders'. ${ }^{78}$ The current EAC was established in 1999 through the signing of the Treaty for the Establishment

\footnotetext{
${ }^{76}$ Eastern and Southern African Trade Bank v Ogang 2001 East African Law Reports 46.

77 Ahmed Mohiddin "Introduction: Deepening Political Integration in the East African Community" in Ahmed Mohiddin Deepening Regional Integration of the East African Community (2005) 1.

${ }^{78} \mathrm{C}$ Jacobeit et al Overlapping Membership in COMESA, SACU and SADC 17.
} 
of the East African Community. The EAC's agenda on integration goes beyond economic integration to incorporate political integration. ${ }^{79}$ The economic integration agenda has been aggressively pursued and the EAC is unusual in that it chose to start its integration with a customs union rather than a free trade area.

The East African Court of Justice (EACJ) was established in terms of the Treaty Establishing the East African Community. ${ }^{80}$ Like the CoJ, the court is charged with the interpretation and application of EAC Treaty Law. ${ }^{81}$ Exclusive jurisdiction over matters arising in and out of the EAC Treaty is granted to the EACJ. ${ }^{82}$ Decisions of the court are final, binding and conclusive and not open to appeal. ${ }^{83}$ Fifteen judges are appointed for a maximum of seven years each. ${ }^{84}$ This is quite a large number of judges for such a small community of states and possibly adds to greater expenses when the court is in session. However, a remarkable fact is that the amendment of the EAC Treaty in 2006 created a First Instance Division and an Appellate Division composed of ten and five judges respectively. ${ }^{85}$

The decisions of the EACJ relating to the interpretation and application of the EAC Treaty have precedence over those of national courts. ${ }^{86}$ Partner states may request advisory opinions from the EACJ; likewise the EAC Council. ${ }^{87}$ While the EAC first sat in 2001 , it still has neither a permanent seat nor sitting. The court only sits when the

\footnotetext{
${ }^{79}$ In the Treaty, the Member States undertake to establish ... a Customs Union, a Common Market, subsequently a Monetary Union and ultimately a Political Federation in order to strengthen and regulate the industrial, commercial, infrastructural, cultural, social, political and other relations of the Partner States to the end that there shall be accelerated, harmonious and balanced development and sustained expansion of economic activities, the benefit of which shall be equitably shared.

${ }^{80}$ E Mugisa, C Onyango and P Mugoya, "An Evaluation of the Implementation of the East African Community Customs Union" Final Report, March 2009.

${ }^{81}$ Article 23(1) of the EAC Treaty.

${ }^{82}$ Article 38(1).

${ }^{83}$ Article 35(1).

${ }^{84}$ Article 25(1).

${ }^{85}$ Article 24(2).

${ }^{86}$ Article 33 (2).

${ }^{87}$ Article 36 .
} 
need to do so arises. The temporary seat of the court is in Arusha, Tanzania, but other sittings have been held in Mombasa, Dar es Salaam and Kampala. ${ }^{88}$ Such a scenario raises pertinent questions relating to the envisaged TFTA Dispute Settlement Body as partners will have to decide on a strategic location for their court.

Following the decision in Prof. Peter Anyang' Nyong'o and Others v. Attorney General of Kenya and Others, ${ }^{89}$ the jurisdiction of the court was expanded to include an appeal from a national division. In the Nyong'o case, the court decided that, despite having no locus standi, the citizens of Kenya could challenge the appointment of the Kenyan representatives to the East African Parliament. The EAC Council reacted to this decision by calling for amendments to the Court's power, resulting in the 2006 Amendments. ${ }^{90}$ This in turn spurred calls for the EACJ to allow appeals from national courts in order to strengthen judiciaries within the region and harmonise the judicial systems of the partners and the EAC. ${ }^{91} \mathrm{~A}$ move to harmonise the laws of the TFTA member states would be a cumbersome process, especially if pitched at the level that the EAC wants to achieve. A less onerous but equally challenging move would be the harmonisation of trade and investment policies. That way, a TFTA-wide trade agenda could be sculpted as against external trade partners.

Subsequent to the 2006 Amendments, the East African Law Society levelled a challenge against the EAC Council based on the legality of the ratification

\footnotetext{
88 James T Gathii, JT African Regional Trade Agreements as Legal Regimes (2011) 268-9.

${ }^{89}$ Prof. Petter Anyang' Nyong'o and Others v. Attorney General of Kenya and Others, EACJ, Ref. No. 1 of 2006 (30 March 2007). The claimants contended that Kenya had violated Article 50 of the EAC Treaty calling for representative appointment of member s of the EAC Legislature.

${ }^{90}$ Gathii African Regional Trade Agreements at 275. These include the restructuring of the court into the First Instance and Appellate Divisions; the addition of a two-month time limit to cases brought by legal and natural persons; and limiting the court's jurisdiction to jurisdiction conferred by the Treaty on organs of partner states.

91 lbid at 270.
} 
procedures that were employed for the amendments. ${ }^{92}$ The EACJ concluded that the ratification process that was used in making the amendments constituted an infringement of the amendment rules in the Treaty because the private sector and civil society were not consulted during the drafting of the amendments. However, the court cautioned that despite the lack of procedurally sound enactment, the amendments were in line with the Treaty's objectives.

In James Katabazi and 21 Others $v$ Secretary General of the East African Community and Another, ${ }^{93}$ the court dealt with the lawfulness of the detention of Ugandan prisoners charged with treason. Jurisdiction of the court over human rights matters was challenged by the respondents, who contended that no such jurisdiction had been granted in terms of the EAC Treaty. The court held that despite this limitation on its power, the dispute fell under EAC law; hence a decision could be made. The extension of the court's authority into the realm of human rights went beyond the ordinary scope of the EACJ's work. However, it highlights the progressive nature of the court's decision-making, which fact could be useful in encouraging a more independent role for the TFTA tribunal. This is a direct contrast to the political interference occasioned in the Nyong'o case. Nonetheless, the test of the continued independence of the court still remains to be seen. Ground-breaking judgments tend to aggravate state parties.

\section{(c) The SADC Tribunal}

The SADC Trade Protocol is the primary determinant of the SADC economic agenda. Its objectives include: liberalisation of trade; ensuring efficient production

\footnotetext{
${ }^{92}$ East African Law Society and Others $v$ Attorney General of the Republic of Kenya and Others, EAC Judgment Ref. No. 3 of 2007(Sept. 2008).

93 James Katabazi and 21 Others $v$ Secretary General of the East African Community and Another, EACJ Judgment Ref. No. 1 of 2007 (1 Nov 2007).
} 
within SADC; improving the climate for domestic, cross-border and foreign investment; enhancing of economic development, diversification and industrialisation; and, establishing a Free Trade Area (FTA) by $2008 .^{94}$ The intended FTA was launched at the SADC Heads of State and Government Summit in August 2008.

The SADC Tribunal was established to interpret the provisions of the SADC Treaty and to adjudicate on any disputes arising out of its provisions and those of subsidiary instruments. ${ }^{95}$ The Tribunal was made up of ten members of high judicial standing in their countries of origin, appointed for a five-year term renewable for the same period upon expiry if the first term. ${ }^{96}$ Five of these were regular members, while the others acted as a pool from which substitutes for regular members who were unable to execute their duties could be drawn. ${ }^{97}$ The Tribunal could be constituted by three judges. ${ }^{98}$ It only sat when cases were submitted to it. ${ }^{99}$ Such a model for the appointment and service of judges would be a convenient solution for cases where time and resource constraints arise, leading to delays in the judicial process.

According to the SADC Treaty, the Tribunal could give advisory opinions at the request of the SADC Summit or Council. ${ }^{100}$ The Tribunal had jurisdiction over disputes between states, ${ }^{101}$ disputes between legal and natural persons and states, ${ }^{102}$ disputes between states and the community, ${ }^{103}$ and disputes involving the

\footnotetext{
${ }^{94}$ Article 2 of SADC Trade Protocol.

${ }^{95}$ Article $1(\mathrm{~g})$ and $16(1)$ of the SADC Treaty.

${ }^{96}$ Article 13 and Article 6(1) of the SADC Protocol on Tribunal.

${ }_{97}$ Article 3(2) of the SADC Treaty.

${ }_{98}$ Article 3(3) of the Protocol on Tribunal.

${ }^{99}$ Article 3(4).

100 Art 16(4).

101 Article 15(1).

102 Article 18.

${ }^{103}$ Article 17.
} 
Tribunal and its employees. ${ }^{104}$ However, it is notable that the Tribunal did not have original jurisdiction, unlike the EACJ. Disputes could only be referred to the Tribunal upon the exhaustion of local remedies. ${ }^{105}$

The decisions of the Tribunal were deemed to be final and binding. ${ }^{106}$ This is remarkable in that the Tribunal was further directed to develop its own case law with due regard to general principles of international law. ${ }^{107}$ Such a ground-breaking directive was good in that it allowed the court to create its own precedents and develop community law in such a way that progressive justice could be occasioned. However, this provision was also to prove to be the Achilles heel of the Tribunal through the challenge that arose in the cases relating to Zimbabwe's land reform programme.

In Mike Campbell (Pvt) Ltd. and 78 Others $v$ The Republic of Zimbabwe ${ }^{108}$ the Tribunal heard a challenge by a group of displaced landowners to the land reform programme in Zimbabwe. The Supreme Court of Zimbabwe decided that Amendment 17 of the Zimbabwe Constitution barring appeal to a court to challenge the acquisition of land by the state was in line with government policy regarding land reform. ${ }^{109}$ Since domestic jurisdiction of the courts had been ousted, the Tribunal determined that it had jurisdiction to hear the matter. Counsel for the Government of Zimbabwe alleged that the Tribunal had no proper basis for jurisdiction since this was a human rights issue, for which there was no provision in either the SADC Treaty or the Protocol on the Tribunal. Nevertheless, the Tribunal noted that it was

\footnotetext{
${ }^{104}$ Article 19.

${ }^{105}$ Article 15.

${ }^{106}$ Article 16(5)

${ }^{107}$ Article 15(3).

${ }^{108}$ Mike Campbell (Pvt) Ltd. and 78 Others $v$ The Republic of Zimbabwe, SADC (T) Case No. 2/2007 [2008] SADCT2 (28 Nov. 2008).

109 Mike Campbell (Pty) Ltd. v Minister of National Security Responsible for Land, Land Reform and Resettlement (124/06) [2008] ZWSC 1 (22 Jan. 2008).
} 
mandated to develop its own case law with due regard for the principles of international law. In addition, the SADC Treaty called on member states to act in accordance with human rights, democracy and the rule of law. ${ }^{110}$ Consequently, the Tribunal could hear the matter and make a determination on the merits.

The Tribunal decided that the applicants had been discriminated against on the ground of race; hence the Zimbabwean government owed them fair compensation for their land. Zimbabwe challenged this conclusion on two bases: that it had not ratified the Protocol on the Tribunal and that the Tribunal did not formally exist since the SADC Summit had not determined it. Article 16 of the SADC Treaty states that notwithstanding the provisions of Article 22, which provides that each Protocol is binding on members who have acceded to it; the Protocol on the Tribunal forms an integral part of the Treaty. ${ }^{111}$ This means that the ratification argument is unsustainable since accession to the Protocol is not the only way in which states can be bound by it. Furthermore, the fact that Zimbabwe nominated Justice Antonia Guvava to the Tribunal collapses the contention that Zimbabwe did not believe the Tribunal was in existence. ${ }^{112}$ This argument may have been sustained only if Zimbabwe had not acquiesced to the Tribunal's jurisdiction through defending the matter in Windhoek. Even so, the appointment of a member of the Tribunal was testimony to the fact that Zimbabwe recognised its existence.

Following the failure of the Zimbabwean government to comply with the decision of the Tribunal, a declaration regarding this breach was made in June 2009 and reported it to the Summit. ${ }^{113}$ Despite this move, however, a further case relating to

\footnotetext{
${ }^{110}$ Article 4(c).

${ }^{111}$ Articles 22(2) and $16(2)$ of the SADC Treaty.

112 Gathii African Regional Trade Agreements at 291.

113 William Campbell and Another v The Republic of Zimbabwe SADC (T) Case No. 3/2009 [2009] SADCT1 (5 June 2009).
} 
the land reform programme was heard by the Tribunal in $2010 .{ }^{114}$ In the latter case, the Tribunal found that there were further acts of non-compliance.

One of the applicants in the Campbell case tried to have the order of the Tribunal enforced in Zimbabwe. ${ }^{115}$ The court reaffirmed the decision in Mike Campbell (Pty) Ltd. $v$ Minister of National Security Responsible for Land, Land Reform and Resettlement barring appeal to a court regarding forcible expropriation of land by the government in pursuit of its land reform agenda. It was reiterated that the land reform 'programme, despite its administrative and practical shortcomings, is quintessentially a matter of public policy in Zimbabwe, conceived well before the country attained its sovereign independence. ${ }^{116}$ It is interesting that the court averred to the discordant manner in which the land reform programme had been implemented, yet chose to dismiss the Gramara appeal. While bowing to the dictates of the doctrine of separation of powers is commendable, the decision of the court not to challenge the executive highlights the tensions that exist between judicial orders made at regional level and the call for execution at domestic level.

However, the decisions of South African courts to allow the enforcement of the Tribunal's decision in South Africa added a new dimension to SADC community law, that is, the enforcement of Tribunal decisions through national courts of member states. ${ }^{117}$ This is pursuant to Article 32 of the Protocol on the Tribunal, which

\footnotetext{
${ }_{114}^{114}$ Fick v Zimbabwe, Ruling, SADC (T) Case No. 01/2010 [2010] (July 16 2010).

115 Gramara (Pvt) Ltd. and One Other $v$ The Government of the Republic of Zimbabwe and Two Others (HC 33/09) ZWHHC 1 (26 January 2010).

${ }_{116}$ Mike Campbell (Pty) Ltd. v Minister of National Security Responsible for Land, Land Reform and Resettlement at 15.

117 Gerhard Erasmus "Another Chapter in the SADC Tribunal Saga: South African Court confirms the Tribunal's Costs Order" TRALAC Working Paper No. S12WP09/2012 2. Louis Fick v Government of Zimbabwe in Pretoria High Court 7781/2009 - rulings by the SADC Tribunal registered, i.e. recognised and enforceable in terms of Article 32 of the Protocol on the SADC Tribunal, by the High Court of South Africa.

Government of the Republic of Zimbabwe $v$ Fick \& Others (657/11) [2012] ZASCA 122 (20 SEPTEMBER 2012) - appeal of the Zimbabwe government against the North Gauteng High Court's
} 
provides, inter alia, that member states shall take measures to ensure execution of the decisions of the Tribunal.

The Zimbabwean government held SADC at ransom by refusing to participate in any proceedings involving the Tribunal until the Protocol on the Tribunal was ratified by at least ten of the fifteen SADC states. ${ }^{118}$ Subsequently, the SADC Summit announced a review of the terms of reference of the Tribunal by the World Trade Institute Advisors in August 2010 and thereby a suspension of the Tribunal. ${ }^{119}$ The suspension was extended in May 2011, as well as in August 2012. At the latter Summit, it was decided that a new Protocol be negotiated to restrict individual access to the court and limit its jurisdiction. ${ }^{120}$ 'SADC governments for the most part sat idly by, seemingly pleased to let Zimbabwe take the lead in destroying a judicial body that could one day issue decisions against them as well. ${ }^{121}$ Up until its demise, the SADC Tribunal heard 15 cases, most of which involved disputes with its employees. Only one trade-related case ever came before the court - a case involving trade facilitation measures adopted in the DRC; however, it was not heard because the application was made just before the suspension of the Tribunal. $^{122}$ What happened with the SADC Tribunal could set an example for the future of dispute settlement bodies in the EAC and COMESA, and, going forward, the

registration and enforcement of a SADC Tribunal ruling and the subsequent attachment of Zimbabwe government-owned property in Cape Town was dismissed.

118 Werner Scholtz 'Review of the Role, Functions and Terms of Reference of the SADC Tribunal' (2011) SADC Law Journal 197; Sean Christie 'SADC Leaders Slammed Over Tribunal Shutdown' last accessed from http://.mg.co.za/article/2011-07-01-sadc-leaders-slammed-over-tribunal-shutdown on 16 August 2015.

${ }^{119}$ Nicole Fritz 'Up in Smoke: The SADC Tribunal and the Rule of Law in the Region' South African Foreign Policy Initiative, September 20123.

${ }_{120}$ Cathal Gilbert \& Karl Beck 'Killing Southern Africa's Human Rights Court' last accessed from http://www.thetreadebeat.com/content-type/opinion-analysis/item/78-killing-southern-africa-s-humanrights-court on 16 August 2015.

${ }_{121}$ Ibid.

122 Gerhard Erasmus 'Another Chapter in the SADC Tribunal Saga: South African Court confirms the Tribunal's Costs Order' TRALAC Working Paper No. S12WP09/2012 3. 
TFTA. ${ }^{123}$ Business people and individuals need to be aware of their rights and remedies within the Tripartite setup. A regional court is an important instrument in facilitating regional integration. ${ }^{124}$ It is important that RTA judiciaries be allowed to operate independently and efficiently without undue interference from political elites.

\section{(d) The Tripartite Dispute Settlement System}

The Tripartite Dispute Settlement System is housed under the auspices of Article 38 of the Draft TFTA Agreement and Annex 13 of this Agreement. However, it must be noted that the Ministerial Committee on Trade and Customs shall also hold dispute settlement powers in relation to trade related matters in the TFTA. ${ }^{125}$ How and in what specific circumstances these powers will be exercised, however, is not specified. Article 38 favours the resolution of disputes through cooperation and consultation. ${ }^{126}$ Should dispute resolution under Article 38 fail, recourse shall be had to Annex 13 procedures. ${ }^{127}$ An interesting aspect of Article 38 is the provision granting supremacy of the Draft TFTA Agreement as against the Agreements of the three RECs involved in the formation of the TFTA. ${ }^{128}$ This means that the Agreements of the three RECs will continue to subsist. On the other hand, the nature of engagement between the three RECs and the TFTA is not entirely spelt out in the Draft TFTA Agreement, thus it remains to be seen what the practical implications of this provision entail.

\footnotetext{
123 OSISA 'Advocacy on the SADC Tribunal' last accessed from http://www.osisa.org/hrdb/regional/advocacy-sadc-tribunal on 16 August 2015.

Cathal Gilbert 'A Key Moment for SADC's Tribunal' last accessed from http://www.thetradebeat.com/component/k2/77-a-key-moment-for-sadc-s-tribunal on 16 August 2015. ${ }_{125}$ Article $37(1)$ of the Draft TFTA Agreement.

${ }^{126}$ Article 38(1).

${ }^{127}$ Article 38(3).

${ }^{128}$ Article 38(4) - In the event of inconsistency or a conflict between this Agreement and the treaties and instruments of COMESA, EAC and SADC, this Agreement shall prevail to the extent of the inconsistency or conflict.
} 
In the three RECs, individuals and private organisations were allowed to the approach DSB after exhausting local remedies. However, the suspension of the SADC Tribunal has left this avenue open only to legal and natural persons in the EAC and COMESA. In the TFTA, as in the WTO, only states may file disputes with the DSB. ${ }^{129}$ Perhaps standing should be given to both natural and legal persons at the TFTA level given the nature of trade in Africa, as alluded to above.

Similarities exist between the WTO dispute settlement system and that of the TFTA. Both systems envisage the resolution of disputes following a four stage process. ${ }^{130}$ Consultation sand consultation periods are similar. During consultations, good offices, conciliation and mediation may be engaged in an attempt to resolve a conflict. Upon the failure of consultations to resolve a dispute, any of the parties to a dispute can request that a Panel be established to consider the matter. Submissions, arguments and rebuttals are made on paper; however, oral arguments may be invited. ${ }^{131}$ After a hearing, the Panel issue an interim report which is available for comment from the parties to the dispute, following which a Final Report with Recommendations will be issued. ${ }^{132}$ Arbitration is an option which can be used to avert the expense and time involved in adversarial dispute resolution. Clearly the WTO is followed in this dispute resolution process.

Differences do, however, exist between the two bodies. Dispute settlement at the TFTA is concerned with a violation of TFTA law, while that at the WTO involves the covered agreements. ${ }^{133}$ At the WTO, requests for consultations are sent directly to the DSB, while at the TFTA, they are sent to the Chief Executive Officers of the three

\footnotetext{
${ }^{129}$ Article 3 of Annex 13; Article 1 of the DSU.

${ }^{130}$ Articles 5-7 of Annex 13; Articles 4-6 of the DSU.

${ }^{131}$ Article 11 of Annex 13; Article 12 of the DSU.

${ }^{132}$ Article 14 of Annex 13; Articles 15 and 16 of the DSU.

${ }^{133}$ Article 3 of Annex 13; Article 1 of the DSU.
} 
RECs. ${ }^{134}$ This provision seems rather strange and onerous in light of the fact that the relations between the REC-level dispute settlement bodies and that of the TFTA are not clearly spelt out. Hence it may be easier for aggrieved parties to submit requests directly to the TFTA dispute settlement body. The WTO provides for special procedures for developing countries, while the TFTA is mostly made up of developing countries, hence making it difficult to apply differential treatment. The Draft TFTA Agreement makes no mention of a Secretariat as one of the institutions, but it suddenly crops up in the DSU to exercise "functions and duties in support of this Annex." ${ }^{135}$ What the nature of these duties is is unclear. Conversely, the WTO Secretariat assists with legal, historical and procedural aspects of dispute resolution ${ }^{136}$.

\section{CONCLUSION}

The advent of the TFTA will go a long way towards achieving the dream of an African Economic Community. However, prior to that, a number of issues need to be resolved first. Some states which form part of the three RECs are not part of the TFTA negotiations - for instance - Angola; hence it will be difficult to reach mutually viable solutions. The fact that not all states are participating fully in existing RECs as well as the TFTA negotiations also militates against proper regional integration. Some member states which will join the TFTA are not members of the WTO, hence the application of WTO law versus TFTA law will prove to be quite bothersome. The disparity in economic development, as well as trade relations, may contribute to trade animosity amongst states.

\footnotetext{
${ }^{134}$ Article 4 of Annex 13; Article 4 of the DSU.

135 Article 21 of Annex 13.

${ }^{136}$ Article 27 of the DSU.
} 
The need for an appropriate, effective dispute resolution mechanism could not be more pronounced given the challenges that are faced by the TFTA negotiating parties. Valuable lessons can be learnt in the dispute resolution realm of the existing RECs. It is hoped that the TFTA partners will be able to arrive at mutually agreeable solutions following effective dispute resolution procedures. Being a new court, however, the TFTA mechanism will likely take a while to get off the ground and be deemed credible. Thus it would be expedient to choose cases that are not overly contentious, although this in some way curtails the carriage of justice. This is especially in light of the contentious cases involving Zimbabwe which in some way contributed to the demise of the SADC Tribunal.

A rules-based approach allows even weaker states to experience somewhat the same equality and participation at the multilateral level. Indeed, for the rules to be deemed to have an effect and acquire the respect and recognition they deserve, enforcement should be seen to not only be possible, but also effective. Use of the reverse consensus method to adopt Panel reports as in the WTO would go a long way in ensuring speedy resolution of disputes. A secretariat may have to be established to assist the dispute settlement body in executing its mandate.

Given the fact that Africa has a large informal business sector, allowing individuals to approach the tribunals for the redress of international trade disputes would be a positive step. It would be ideal as well to incorporate the exhaustion of local remedies in the TFTA prior to instituting proceedings at the regional level. Allowing appeals from national courts in order to strengthen judiciaries within the region and harmonise the judicial systems of the partners may also be a useful strategy to bolster the TFTA. This would be instrumental for the TFTA if decisions can be implemented at all levels, more so in national courts. A further dimension to this is 
that such a decision results in states holding each other accountable. By the same token, this could see Zimbabwe enforcing a decision against Zambia in its courts. Consequently, member states will be unable to easily escape liability or be in contempt of court if enforcement is universalised.

The establishment of an appeal court in the TFTA would allow for greater independence of the judicial body in charge of trade dispute settlement. If support for such a move can be garnered, then the problems associated with the lack of political will to enforce or implement decisions could be avoided. Nevertheless, it is important to note that the balance between the sovereign integrity of states (a very important component of the political reality facing African countries) and the separation of powers in the super-regional institution is delicate. Many of the states involved in the formation of the TFTA are likely not interested in an extensive limit on their sovereignty. At the same time, an appeal court which binds all national courts could in fact thwart the regional integration initiative if not carefully managed. However, it is important that this be kept in mind going forward.

The parties will have to decide whether to have a permanent seat for the court. It has to be strategically located to ensure that states wishing to utilise dispute settlement procedures are not unduly burdened, given the vast area which the TFTA occupies. Whether sittings of the judges are held will also depend on the case load which will come before the court. The SADC model of five sitting and five stand-by judges; in addition to the directive for the Tribunal to develop its own case law can be drawn from for guidance. Such appointment and service of judges would be a convenient solution for cases where time and resource constraints arise, leading to delays in the judicial process. This is a compromise which allows for expeditious hearing of cases while ensuring that the pool of judges can be called upon to hear cases. Allowing the 
court to create its own precedents and develop community law independently will ensure that progressive justice is occasioned.

The Nyong'o decision led to the amendment of the EAC Treaty relating to the power of the EACJ. SADC Heads of State also suspended the Tribunal after it was deemed to have over-stepped its mandate. The suspension of the Tribunal has major implications for the future of the TFTA since COMESA and the EAC have functional regional courts. The envisaged trade benefits emanating from the formation of the large trade bloc stand to be torpedoed should a trade dispute settlement mechanism not be properly framed. Such political interference in judicial decision-making may serve to curtail the powers of the court; hence the Tripartite parties should beware such intrusion and attempt to adhere to the separation of powers.

Admittedly, during the negotiation stage of the TFTA, issues of trade dispute settlement are unlikely to hold the fort for some time. However, it is important for negotiators to bear in mind that the trade rules under discussion will require interpretation and application, thus the significance of clear dispute settlement procedures cannot be gainsaid. Whilst state sovereignty and national policy should be respected, any action which impacts negatively on the future Tripartite Dispute Settlement Body - and thereby the regional economic bloc - should be dealt a heavy blow to guard against the demise of an intra-regional court.

While the establishment of a rules-based mechanism is laudable, policies and training on the ground need to be formulated to support the institutional apparatus. It is not enough to only have institutions; their effective running requires a lot more than just institutional structures. The political will to ensure that decisions are carried forward and implemented effectively in line with the overall goals of the TFTA is 
essential in guaranteeing the continued existence and respect for the dispute settlement body. Educational initiatives may also be necessary to allow TFTA officials to empower those involved in trade processes people regarding the avenues for redress available to them in the TFTA. The peaceful settlement of disputes is an important contributor to the success of the judicial body which will be inaugurated. In this way, the regional court can play a big role in fostering confidence in the viability of regional integration initiatives as well as allowing disgruntled parties the opportunity to seek redress where conflicts have arisen. 